Proc. Estonian Acad. Sci. Biol. Ecol., 2005, 54, 4, 310-314

\title{
Preliminary study of Enchytraeidae (Oligochaeta) in the Tunca River (Thrace, Turkey)
}

\author{
Timur Kırgız ${ }^{\mathrm{a}}$, Belgin Çamur-Elipek ${ }^{\mathrm{a}}$, and Naime Arslan ${ }^{\mathrm{b} *}$ \\ a Biology Department, Science and Art Faculty, Trakya University, Edirne, Turkey; timurk@trakya.edu.tr \\ ${ }^{\mathrm{b}}$ Biology Department, Science \& Art Faculty, Osmangazi University, Eskişehir, Turkey \\ Received 12 October 2004, in revised form 3 March 2005

\begin{abstract}
Part of the Tunca River (Tundja) is located in the European part of Turkey, Thrace region. Samples were collected monthly between June 2002 and May 2003 taking duplicates from four stations by using Ekman grab (surface $225 \mathrm{~cm}^{2}$ ).

During the present study 132 specimens were collected from the Tunca River. As a result of the study, a total of 8 species of Enchytraeida, comprising 1 species from the family Propappidae (Propappus volki) and 7 species from the family Enchytraeidae (Henlea perpusilla, Enchytraeus buchholzi, Cognettia glandulosa, C. sphagnetorum, Cognettia sp., Fridericia sp., and Lumbricillus sp.), were identified. All species in this study are new records for the Turkish segment of the Tunca River.
\end{abstract}

Key words: Enchytraeidae, Propappidae, Tunca River, Turkey.

\section{INTRODUCTION}

Oligochaetes are the most diverse and widely distributed group of annelids in terrestrial and freshwater habitats in the world. Several species of primarily terrestrial oligochaetes are often collected from freshwater habitats. Enchytraeids are also considered by some authors as primarily terrestrial. However, the marine and freshwater species account for more than one-third of the known enchytraeid species (Wetzel et al. 2000).

The family Enchytraeidae is often overlooked during studies of the fauna in freshwater habitats. Few authors have studied this family specifically. Apart from

\footnotetext{
* Corresponding author, narslan@ogu.edu.tr
} 
Rota (1994) there is almost no study related to the Enchytraeida fauna (freshwater, marine, and terrestrial fauna) of Turkey. However, some researchers have recorded Enchytraeidae species in their freshwater oligochaete fauna studies (e.g. Geldiay \& Tareen 1972, Tareen 1974, Pop 1974, Moubayed et al. 1987). Up to now, 6 enchytraeids (Marionina argentea (Michaelsen, 1889), Enchytraeus albidus (Henle, 1837), Enchytraeus sp., Fridericia sp., Lumbricillus lineatus (Müller, 1774), and Lumbricillus tuba Stephenson, 1911) have been reported from aquatic systems of different parts of Turkey (Pop 1974, Kazanc1 \& Girgin 1998, Balık et al. 2001, 2004).

Although there are numerous faunistic and limnological studies of the Bulgarian part of the Tunca River (e.g. Uzunov 1980, Uzunov \& Kapustina 1993), there have been only two MSc thesis (Kavaz 1997, Öterler 2003) about the small part of the Tunca River that is located in the European part of Turkey, in the Thrace region). The objective of the present study was to fill a part of this gap by examining the enchytraeids in the Tunca River.

\section{MATERIAL AND METHODS}

As we mentioned before, a part of the Tunca (Tundza, Tundja) River is located in the European part of Turkey. Upstream its area is located in Bulgaria. It joins the Meriç (Maritsa), a boundary river between Turkey and Greece with an upstream area in Bulgaria. Samples were collected monthly between June 2002 and May 2003 taking duplicates from each station by using Ekman grab (the surface area $225 \mathrm{~cm}^{2}$ ). A total of 132 specimens of Enchytraeida were collected from four different stations (Fig. 1) of the Tunca River. Samples were preserved in $4 \%$ formalin in the field, brought to the lab, sorted out, and transferred to $70 \%$ ethyl alcohol. Specimens were prepared for study by dehydrating through $70 \%$, $80 \%, 90 \%, 95 \%$, and absolute ethyl alcohol and mounting in polyvinyl lactophenol or Canada balsam.

\section{RESULTS AND DISCUSSION}

A total of eight species of Enchytraeida, comprising one species from the family Propappidae (Propappus volki Michaelsen, 1916) and seven species from the family Enchytraeidae (Henlea perpusilla Friend, 1911; Enchytraeus buchholzi Vejdovský, 1879; Cognettia glandulosa (Michaelsen, 1889); C. sphagnetorum (Vejdovský, 1878); Cognettia sp.; Fridericia sp.; and Lumbricillus sp.), were identified (Table 1).

The Enchytraeida fauna of the Tunca River was dominated by widely distributed Enchytraeidae species. In our research area, Cognettia glandulosa was the most 


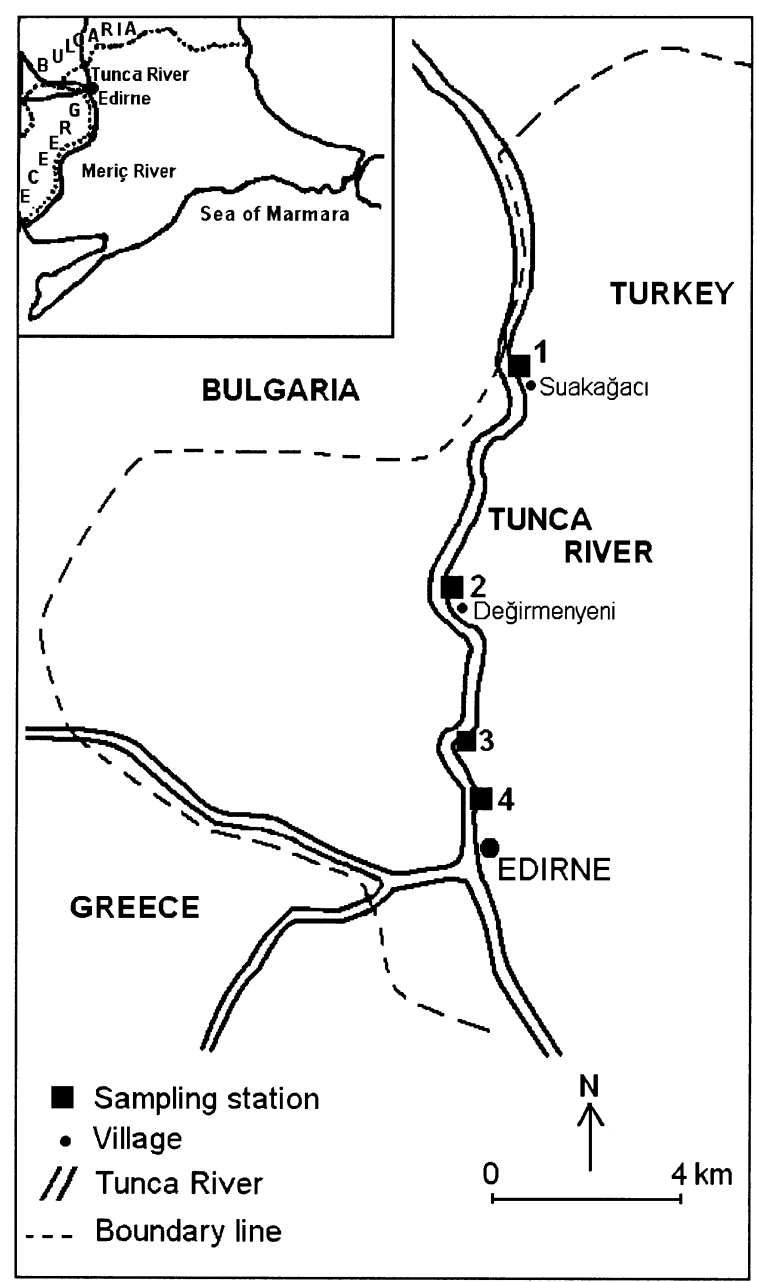

Fig. 1. Geographical situation of the Tunca River and sampling stations.

frequent species followed by Henlea perpusilla and Cognettia sp. among the enchytraeids while Propappus volki was restricted to one sampling site (Table 1). The species $P$. volki prefers sandy bottom. Station 1 , where $P$. volki was observed, also possesses these characteristics. Two of the taxa observed from the Tunca River, Enchytraeus buchholzi and Fredericia sp., were previously reported from Işıklı Lake (Balık et al. 2000) and Ankara Stream (Kazanc1 \& Girgin 1998), respectively. As there has been no investigation related to the oligochaete fauna of the Tunca River before, all the species in this study are new records for the Turkish segment of this river. 
Table 1. Species composition of Enchytraeida, sampling site characteristics (minimum and maximum values), and the number of identified specimens in the Turkish segment of the Tunca River

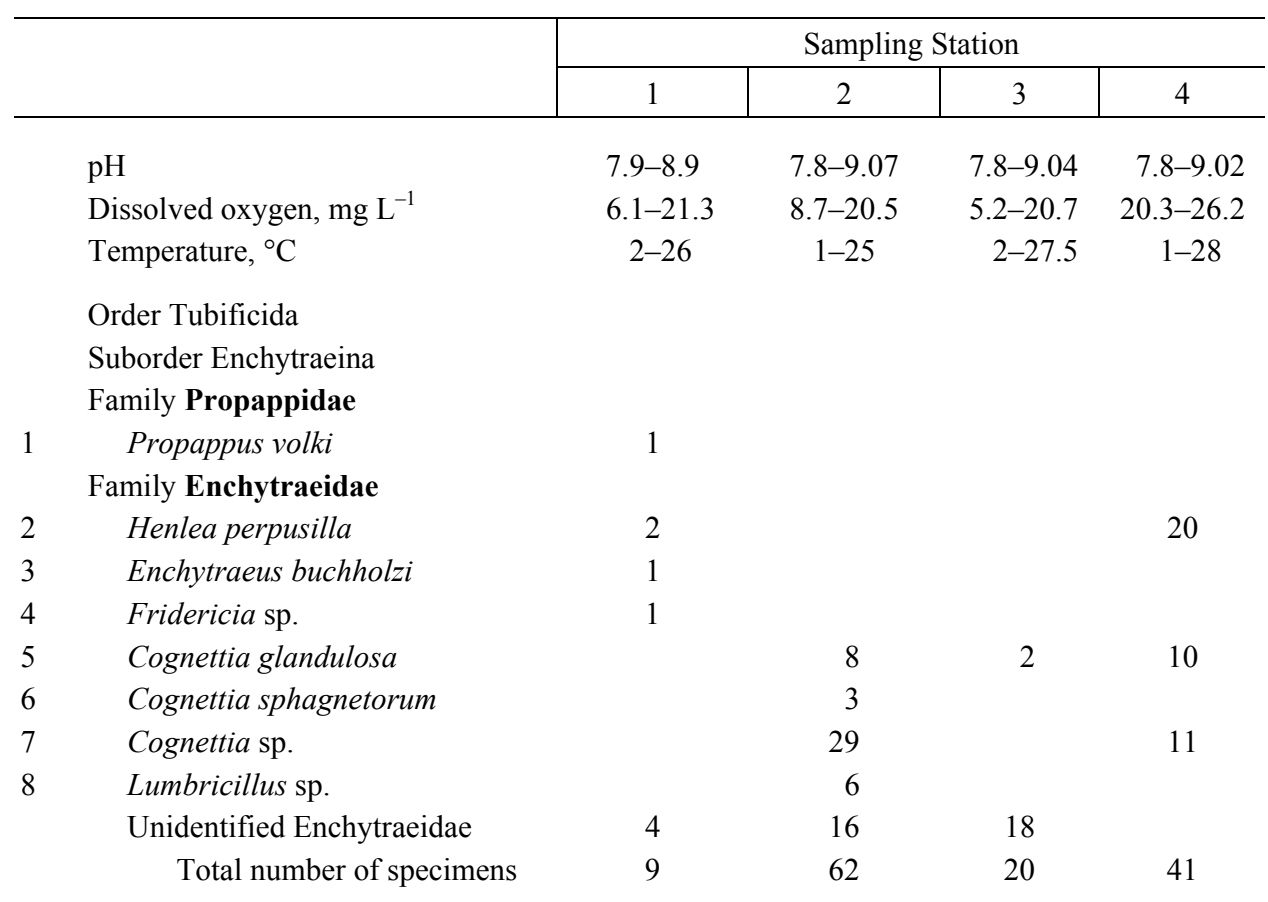

Enchytraeida fauna of many aquatic ecosystems has still not been investigated in Turkey. Therefore, further investigation on the freshwater Enchytraeida fauna in Turkey is necessary.

\section{REFERENCES}

Balık, S., Ustaoğlu, M. R., Taşdemir, A. \& Yıldız, S. 2000. Benthic fauna of Işıklı Lake (ÇivrilDenizli). In $X V$. National Biology Symposium, Vol. I, pp. 210-216. Ankara.

Balık, S., Ustaoğlu, M. R., Yıldız, S. \& Taşdemir, A. 2001. Benthic fauna (Oligochaeta-Chironomidae) of Sazlıgöl Lake (Menemen-İzmir). In XI. National Fisheries Symposium, pp. 198-205. Hatay.

Balık, S., Ustaoğlu, M. R. \& Y1ldız, S. 2004. Oligochaeta and Aphanoneura (Annelida) fauna of the Gediz Delta (Menemen-İzmir). Turk. J. Zool., 28, 183-197.

Geldiay, R. \& Tareen, I. U. 1972. Bottom fauna of Gölcük Lake, 1. Population study of Chironomids, Chaoborus and Oligochaeta. Scientific Reports of Faculty of Science, Ege University, No. 137 (in Turkish).

Kazanc1, N. \& Girgin, S. 1998. Distribution of Oligochaeta species as bioindicators of organic pollution in Ankara Stream and their use in biomonitoring. Turk. J. Zool., 22, 83-87.

Kavaz, E. 1997. Macroinvertebrates fauna of Tunca River. MSc thesis. Trakya University, Edirne (in Turkish). 
Moubayed, Z., Giani, N. \& Ansemil-Martinez, E. 1987. Distribution of aquatic Oligochaeta and Aphanoneura in the Near East. In Proceedings of the Symposium on the Fauna and Zoogeography of the Middle East, Mainz 1985 (Krupp, F., Schneider, W. \& Kinzelbach, R., eds.). Beih. Tavoa, Wiesbaden, 28, 80-90.

Öterler, B. 2003. An investigation on Tundza River phytoplankton and their relationship with water quality. MSc thesis. Trakya University (in Turkish).

Pop, V. C. 1974. Faunistische Forschungen in den Grundwässern des Nahen Ostens. XII. Oligochaeta (Annelida). Arch. Hydrobiol., 73, 108-121.

Rota, E. 1994. Enchytraeidae (Oligochaeta) of western Anatolia: taxonomy and faunistics. Boll. Zool., 61, 241-260.

Tareen, I. U. 1974. Limnological investigations of Gölcük Lake (Ödemiş-Turkey). PhD thesis. Ege University, Zoology Department, Faculty of Science (in Turkish).

Uzunov, Y. 1980. Water oligochets (Oligochaeta, Limicola) from some Bulgarian rivers. Frequency and domination. Hydrobiology (Sofia), 12, 79-89.

Uzunov, Y. \& Kapustina, L. 1993. Current review on Oligochaeta from macrozoobenthic communities of the Bulgarian Rivers. Lauterbornia, 13, 73-83.

Wetzel, M. J., Kathman, R. D., Fend, S. V. \& Coates, K. A. 2000. Taxonomy, Systematics and Ecology of Freshwater Oligochaeta. Workbook prepared for North American Benthological Society Technical Information Workshop, 48th Annual Meeting, Keystone Resort, CO.

\title{
Tunca jõe (Traakia, Türgi) Enchytraeidae fauna esialgne uuring
}

\author{
Timur Kırgız, Belgin Çamur-Elipek ja Naime Arslan
}

Uuriti Tunca jõe Türgi piiresse jäävat alamjooksu. Aastail 2002 ja 2003 põhjaammutiga kogutud proovidest määrati 7 taksonit sugukonnast Enchytraeidae (Henlea perpusilla, Enchytraeus buchholzi, Cognettia glandulosa, C. sphagnetorum, Cognettia sp., Fridericia sp. ja Lumbricillus sp.), lisaks Propappus volki sugukonnast Propappidae. 